Article

\title{
Influence of Cementitious System Composition on the Retarding Effects of Borax and Zinc Oxide
}

\author{
Feraidon F. Ataie \\ Concrete Industry Management Program, California State University, Chico, CA 95929, USA; \\ fataie@csuchico.edu
}

Received: 4 June 2019; Accepted: 23 July 2019; Published: 24 July 2019

\begin{abstract}
This research investigated the retarding impact of zinc oxide $(\mathrm{ZnO})$ and borax $\left(\mathrm{Na}_{2}\left[\mathrm{~B}_{4} \mathrm{O}_{5}(\mathrm{OH})_{4}\right] \cdot 8 \mathrm{H}_{2} \mathrm{O}\right)$ on hydration of Portland cement, calcium aluminate cement (CAC), and calcium sulfoaluminate cement (CSA). Heat of hydration of cement paste samples with and without $\mathrm{ZnO}$ and borax was used to measure the influence of $\mathrm{ZnO}$ and borax on the set time of these cementitious systems. It was found that both $\mathrm{ZnO}$ and borax can retard the set time of Portland cement systems; however, $\mathrm{ZnO}$ was shown to be a stronger set time retarder than borax for these systems. ZnO did not show any retarding impact on CAC and CSA systems while addition of borax in these systems prolonged the set time. It was concluded that $\mathrm{ZnO}$ does not poison the nucleation and/or growth of CSA and CAC hydration products. We suggest that borax retards the cement set time by suppressing the dissolution of cement phases.
\end{abstract}

Keywords: zinc oxide; borax; set time; heat of hydration; calcium aluminate cement; calcium sulfoaluminate cement

\section{Introduction}

Utilization of cement set time retarders, referred to as retarding admixtures, in concrete allows concrete producers to delay the set time of concrete. Retarding admixtures are commonly used in hot weather concreting and when ready mixed concrete should be transported for a long distance. Sucrose (sugar) is a well-known cement set retarder [1-5]. Sucrose retards cement hydration by poisoning nucleation sites for calcium silicate hydrate $(\mathrm{C}-\mathrm{S}-\mathrm{H})[3,6]$. This poisoning effect prevents the formation of $\mathrm{C}-\mathrm{S}-\mathrm{H}$ for an extended period and thus delays the cement set time. The following abbreviations will be used in this paper: $\mathrm{H}=\mathrm{H}_{2} \mathrm{O}, \mathrm{C}=\mathrm{CaO}, \mathrm{A}=\mathrm{Al}_{2} \mathrm{O}_{3}, \hat{\mathrm{S}}=\mathrm{SO}_{3}, \mathrm{~S}=\mathrm{SiO}_{2}$.

Zinc oxide $(\mathrm{ZnO})$ has been shown to be another strong cement set retarder [7-9]. It has been suggested that $\mathrm{ZnO}$, like sucrose, poisons $\mathrm{C}-\mathrm{S}-\mathrm{H}$ nucleation sites and thus retards the cement set time [7]. In cementitious systems containing $\mathrm{ZnO}$, during the prolonged dormant period, cement particles continue to dissolve and thus the concentration of ions in the pore solution increases [3,7]. This will increase calcium concentration in the system leading to an increase in C-S-H nucleation sites. Therefore, the rate at which C-S-H grows after the set time is higher in systems containing $\mathrm{ZnO}$ compared to those without any retarder. This is why $\mathrm{ZnO}$ is called a "delayed accelerator" [7].

The retardation time of cementitious systems containing $\mathrm{ZnO}$ is correlated to the amount of $\mathrm{Zn}$ ions dissolved in the pore solution [7]. The higher the $\mathrm{Zn}$ ion concentration in the pore solution, the longer the retardation period. The retardation period caused by $\mathrm{ZnO}$ is suggested to end by two possible mechanisms [7]: (1) removal of $\mathrm{Zn}$ ions from the pore solution by chelation or adsorption of $\mathrm{Zn}$ ions by hydration products, such as $\mathrm{C}-\mathrm{S}-\mathrm{H}$; and (2) removal of $\mathrm{Zn}$ ions by formation of calcium zinc hydrate according to Equations (1) and (2) [10,11].

$$
\mathrm{ZnO}+\mathrm{H}_{2} \mathrm{O}+2 \mathrm{OH}^{-} \rightarrow \mathrm{Zn}(\mathrm{OH})_{4}^{2-}
$$




$$
\mathrm{Zn}(\mathrm{OH})_{4}^{2-}+\mathrm{Ca}^{++}+\mathrm{H}_{2} \mathrm{O} \rightarrow \mathrm{Ca}\left(\mathrm{Zn}(\mathrm{OH})_{3}\right)_{2} \cdot 2 \mathrm{H}_{2} \mathrm{O}+2 \mathrm{OH}^{-}
$$

Borax is another set time retarder for cementitious systems [12]. It has been shown that borax delays the set time of calcium sulfoaluminate cement (CSA) by preventing the dissolution of ye'elimite [12].

The behavior of retarding admixtures in cementitious systems depends on several factors, such as the composition of the systems as well as the curing temperature. Addition of supplementary cementitious materials (SCM), such as rice straw ash and silica fume, in cementitious systems have been shown to reduce the retarding action of chemical retarders $[7,13]$. This has been attributed to existence of more $\mathrm{C}-\mathrm{S}-\mathrm{H}$ nucleation sites in systems containing SCMs compared to those without SCMs $[7,13,14]$. Therefore, the composition of the cementitious system affects the chemical admixture performance in the system.

The dissolution of $\mathrm{ZnO}$ in alkaline solutions (such as cementitious solutions) increases as the temperature increases [15]. Similarly, cement early hydration, and thus the formation of C-S-H, increases as the curing temperature increases [16]. It is not known, however, as to how the curing temperature could affect the retarding action of $\mathrm{ZnO}$ on cementitious systems.

Although the impact of $\mathrm{ZnO}$ on Portland cement hydration has been studied by some researchers, the influence of $\mathrm{ZnO}$ on hydration of calcium aluminate cement (CAC) and on CSA has not been investigated yet. As the composition of CAC and CSA and their hydration mechanisms are different than that of Portland cement, it would be expected that $\mathrm{ZnO}$ and borax would affect the hydration of CAC, CSA, and Portland cement in different ways.

This study investigates the impact of $\mathrm{ZnO}$ and borax on the Portland cement, CAC, and CSA hydration process. Furthermore, the influence of the curing temperature on the retarding action of $\mathrm{ZnO}$ is studied.

\section{Materials and Methods}

ASTM C150 [17] Type II/V and Type III as well as commercially available CAC and CSA cements were used in this study. The chemical composition of the cementitious materials is shown in Table 1. ACS grade zinc oxide was used. The borax used was ACS grade sodium tetraborate decahydrate $\left(\mathrm{Na}_{2}\left[\mathrm{~B}_{4} \mathrm{O}_{5}(\mathrm{OH})_{4}\right] \cdot 8 \mathrm{H}_{2} \mathrm{O}\right)$. Fifty percent food grade citric acid solution was used to stabilize the set time of the CSA cement.

Table 1. Oxide composition of cementitious materials.

\begin{tabular}{ccccc}
\hline & CSA & CAC & Type II/V & Type III \\
\hline $\mathrm{SiO}_{2}$ & 8.32 & 4.79 & 21.3 & 21 \\
\hline $\mathrm{Al}_{2} \mathrm{O}_{3}$ & 21.8 & 40.17 & 3.9 & 5.1 \\
\hline $\mathrm{Fe}_{2} \mathrm{O}_{3}$ & 2.8 & 15.51 & 3.8 & 1.2 \\
\hline $\mathrm{CaO}$ & 43.3 & 37.29 & 63.2 & 64.2 \\
\hline $\mathrm{SO}_{3}$ & 22.8 & - & 2 & 3.6 \\
\hline $\mathrm{MgO}$ & 0.65 & - & 2.2 & 2.2 \\
\hline Blain $\left(\mathrm{cm}^{2} / \mathrm{gr}\right)$ & 5924 & 4065 & 3800 & 5550 \\
\hline
\end{tabular}

The retarding action of $\mathrm{ZnO}$ and borax on cementitious systems was determined by measuring the heat of hydration of cement paste samples using a four-channel isothermal calorimeter. A 0.45 water to cementitious material ratio $(\mathrm{w} / \mathrm{cm})$ was used. When $\mathrm{ZnO}$ or borax was used in paste samples, they were added to dry cementitious material and mixed for one minute by hand before addition of mixing water to the sample. This was done to make sure $\mathrm{ZnO}$ and borax particles were distributed evenly throughout the sample. Several $\mathrm{ZnO}$ and borax dosages were used; all dosages are given as \% mass of cementitious material. 
Paste samples were mixed with an overhead mixer at $600 \mathrm{rpm}$ for $120 \mathrm{~s}$, followed by a $60 \mathrm{~s}$ rest period, and then mixed at $600 \mathrm{rpm}$ for $60 \mathrm{~s}$. The mass of cement pastes samples was approximately $50 \mathrm{~g}$, except for CSA samples that were approximately $15 \mathrm{~g}$. For a given mix, two test samples were prepared for measuring the heat of hydration; the reported result of the heat of hydration is based on the average of the two samples. To obtain the induction period (retardation time), the slope of the acceleration peak of the heat of hydration was extended to the x-axis (time axis). The intersection point between the extended slope and $\mathrm{x}$-axis was considered as the induction (dormant) period as shown in Figure 1 [7].

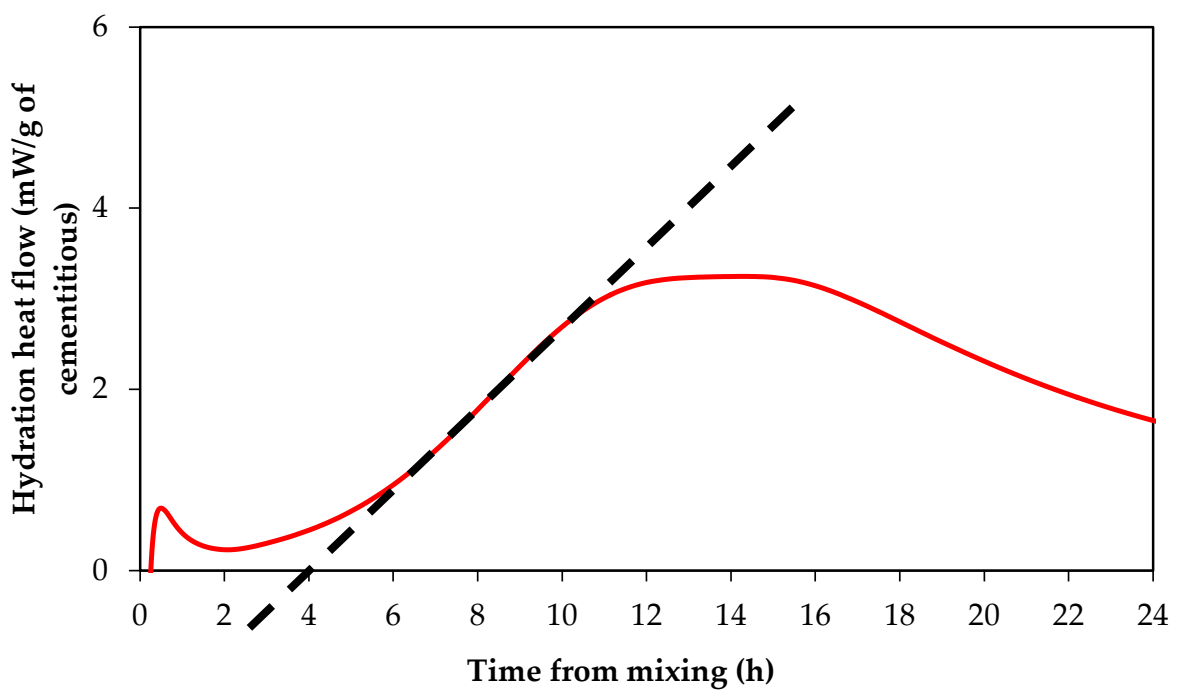

Figure 1. Schematic method of determining the induction period.

\section{Results and Discussions}

\subsection{Impact of Curing Temperature on $\mathrm{ZnO}$ Retarding Action}

Experiments were conducted to investigate the impact of curing temperatures on $\mathrm{ZnO}$ retarding action on cementitious systems. Figure 2 shows the impact of curing temperature on type II/V paste samples with and without $\mathrm{ZnO}$. Figure 3 presents the influence of curing temperature on Type III samples with and without $\mathrm{ZnO}$. As can be seen from these figures, the curing temperature has a huge impact on $\mathrm{ZnO}$ retardation action in cementitious systems; the higher the curing temperature, the shorter the retardation time. Figure 4 plots curing temperatures versus retardation time of paste samples with $0.3 \% \mathrm{ZnO}$ and $0.5 \% \mathrm{ZnO}$. There seems to be an exponential correlation between curing temperature and retardation time of paste samples containing $\mathrm{ZnO}$. Another interesting trend that can be seen for samples that were cured at $50{ }^{\circ} \mathrm{C}$ is that the main hydration peak height is lower from samples containing $\mathrm{ZnO}$ compared to the control sample (with no $\mathrm{ZnO}$ ). This is the opposite of samples cured at $23^{\circ} \mathrm{C}$ or $10^{\circ} \mathrm{C}$.

It has been proposed that the higher the curing temperature is, the higher the rate of the hydration reaction is [18]; this could mean that at higher curing temperatures, $\mathrm{C}-\mathrm{S}-\mathrm{H}$ nuclei are initiated at a faster rate. It has also been shown that higher curing temperatures increase the calcium hydroxide $(\mathrm{CH})$ nucleation rate [19]. This increase in C-S-H and $\mathrm{CH}$ nuclei at higher curing temperatures could be the reason behind the suppressed retardation action of $\mathrm{ZnO}$ in cement paste, as shown in Figures 2 and 3 . It could be proposed that the poisoning effect of $\mathrm{ZnO}$ is overcome sooner at high curing temperatures compared to low curing temperatures due to an increase in $\mathrm{C}-\mathrm{S}-\mathrm{H}$ nuclei at high curing temperatures.

Comparing Figures 2 and 3, it can be observed that, for a given curing temperature and $\mathrm{ZnO}$ dosage, type III samples had a shorter retardation time compared to those samples made with type II/V. This is because type III is finer that type II/V and this results in a higher rate of cement dissolution and a higher number of $\mathrm{C}-\mathrm{S}-\mathrm{H}$ nuclei during early stages of hydration. Therefore, the number of $\mathrm{C}-\mathrm{S}-\mathrm{H}$ 
nuclei in systems containing type III cement would be more than of those containing type II/V. Because of this, the poisoning ability of $\mathrm{ZnO}$ in systems containing type III will deplete faster than in systems with type II/V.
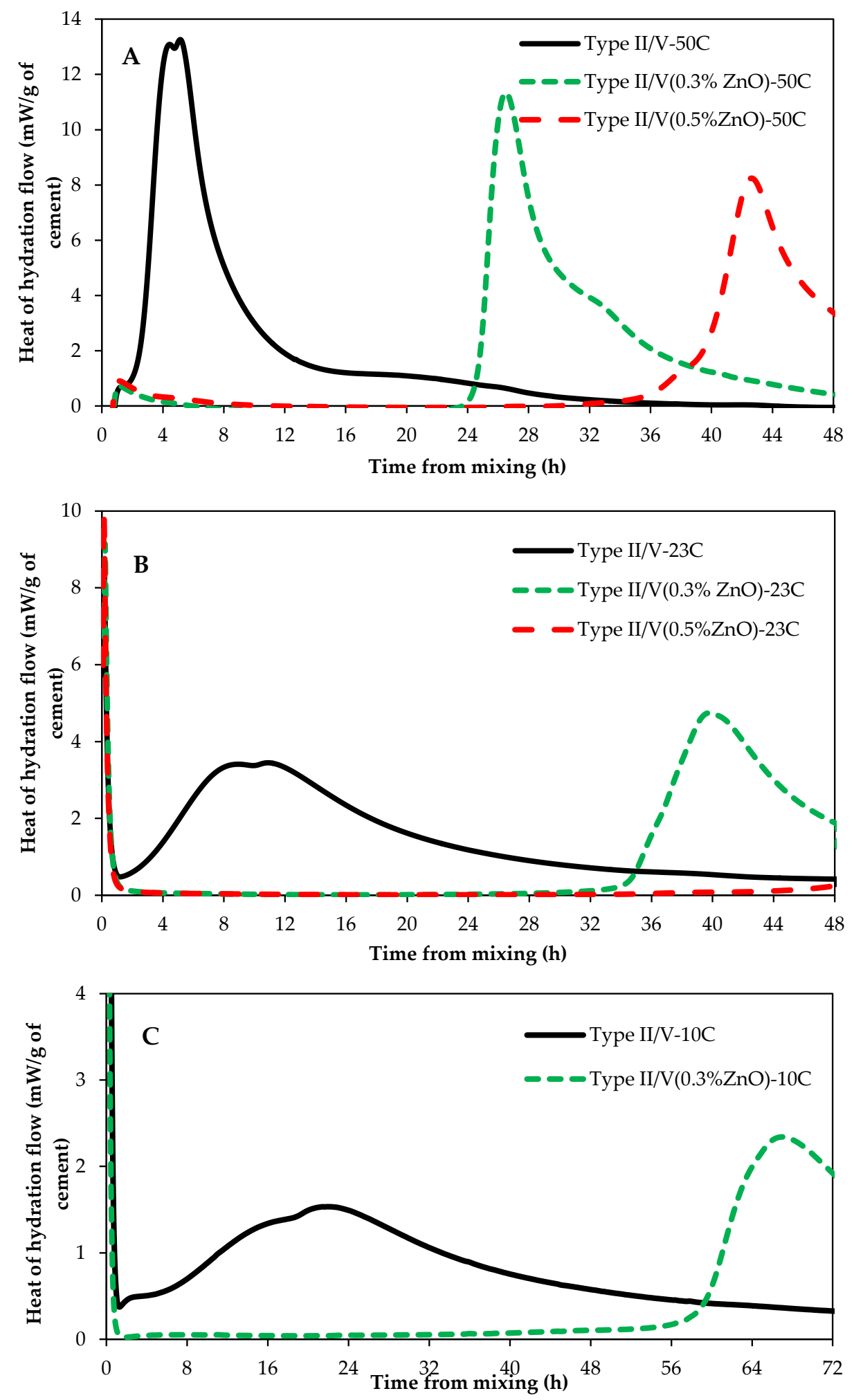

Figure 2. Type II/V heat of hydration at different curing temperatures; (A) $50{ }^{\circ} \mathrm{C},(\mathbf{B}) 23{ }^{\circ} \mathrm{C}$ and (C) $10{ }^{\circ} \mathrm{C}$. 

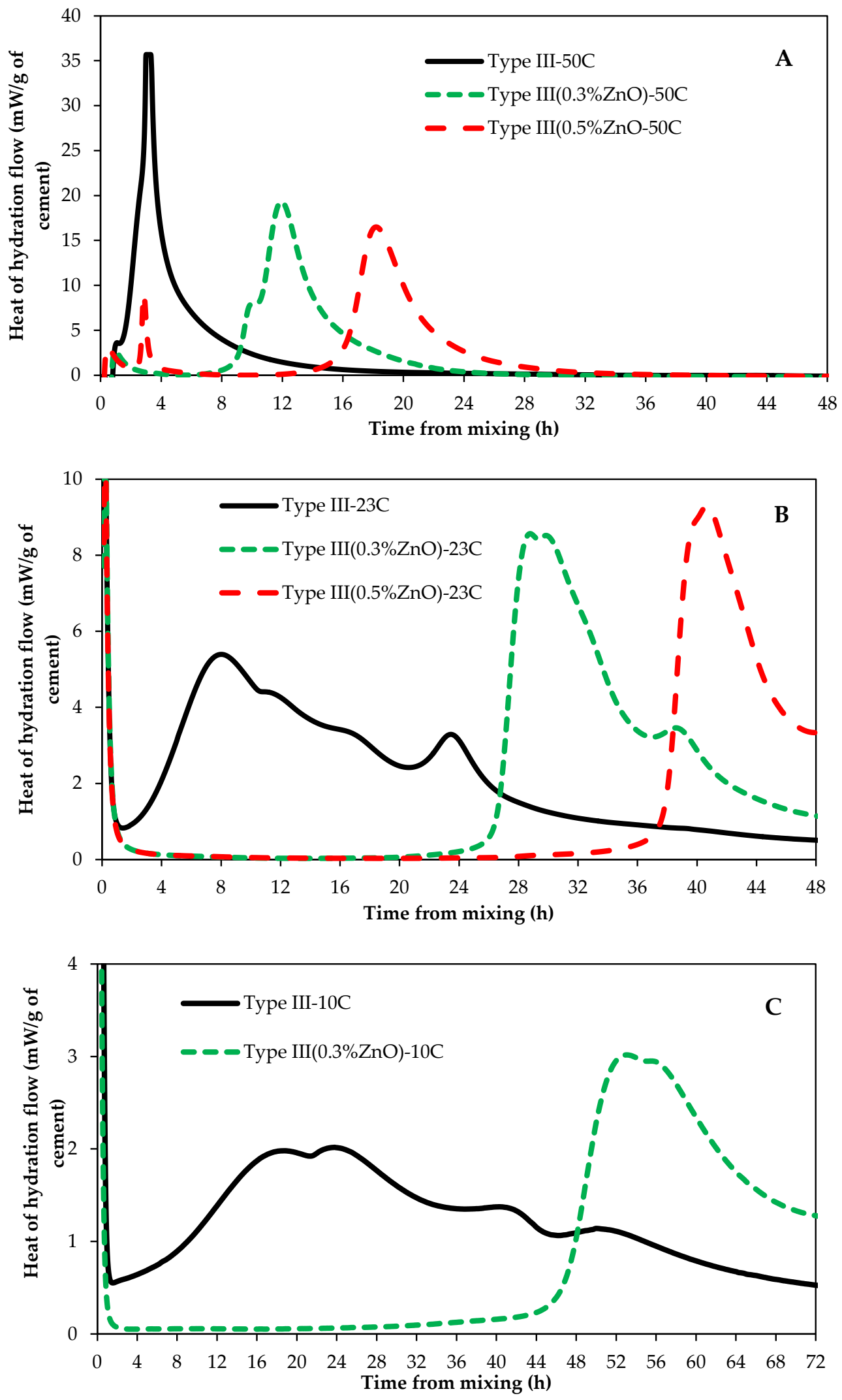

Figure 3. Type III heat of hydration at different curing temperatures; (A) $50^{\circ} \mathrm{C},(\mathbf{B}) 23^{\circ} \mathrm{C}$ and (C) $10^{\circ} \mathrm{C}$. 


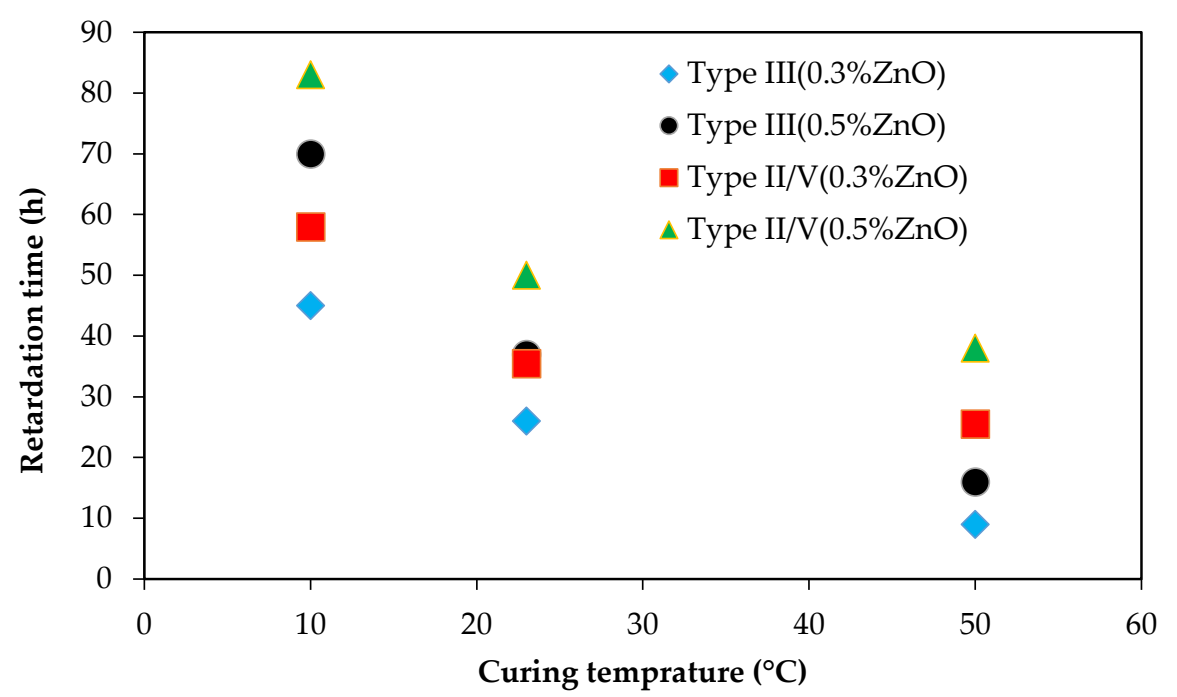

Figure 4. Correlation between curing temperature and retardation time.

\subsection{Influence of Borax on Portland Cement Hydration}

The impact of borax on the heat of hydration of type II/V and type III cement paste is presented in Figures 5 and 6 . These samples were cured at $23^{\circ} \mathrm{C}$. In general, addition of borax in paste samples made with type II/V and type III delayed the set time. However, up to $0.5 \%$ dosage of borax had a negligible effect on the induction period of type III samples (refer to Figure 6).

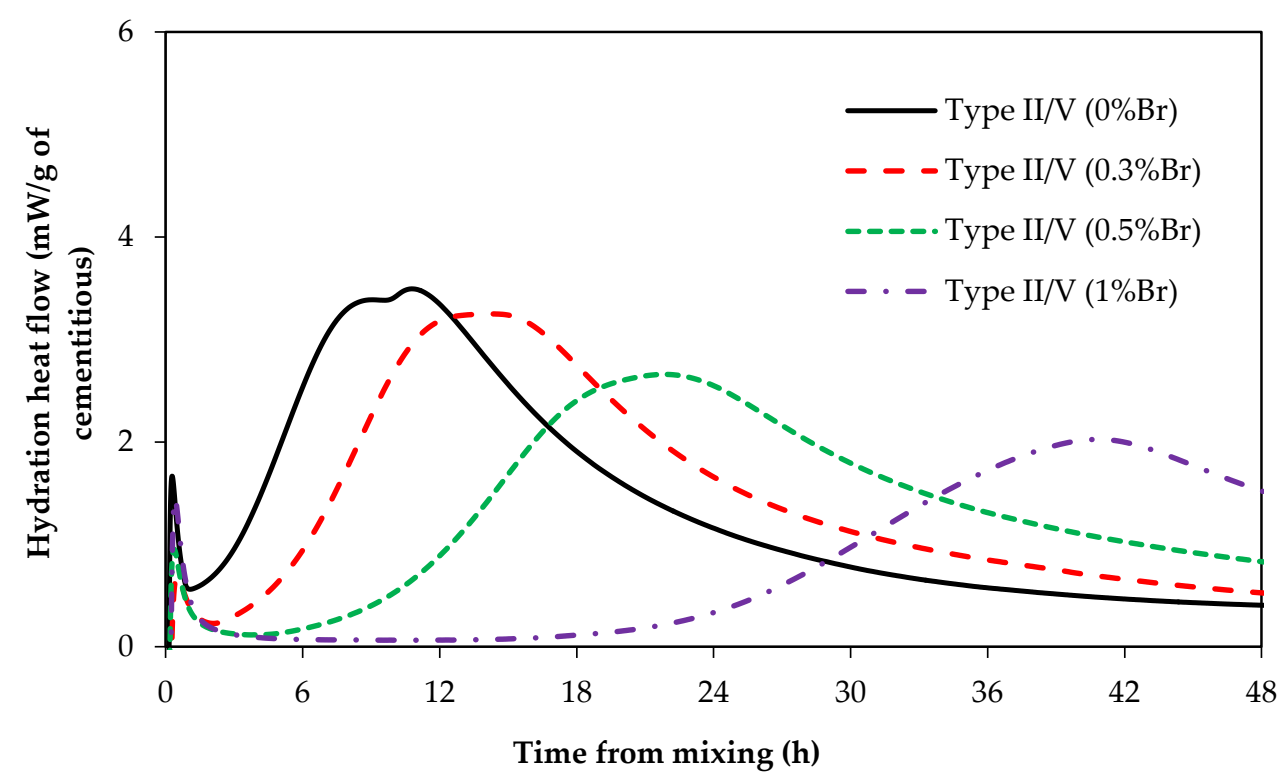

Figure 5. Type II/V hydration with and without borax. 


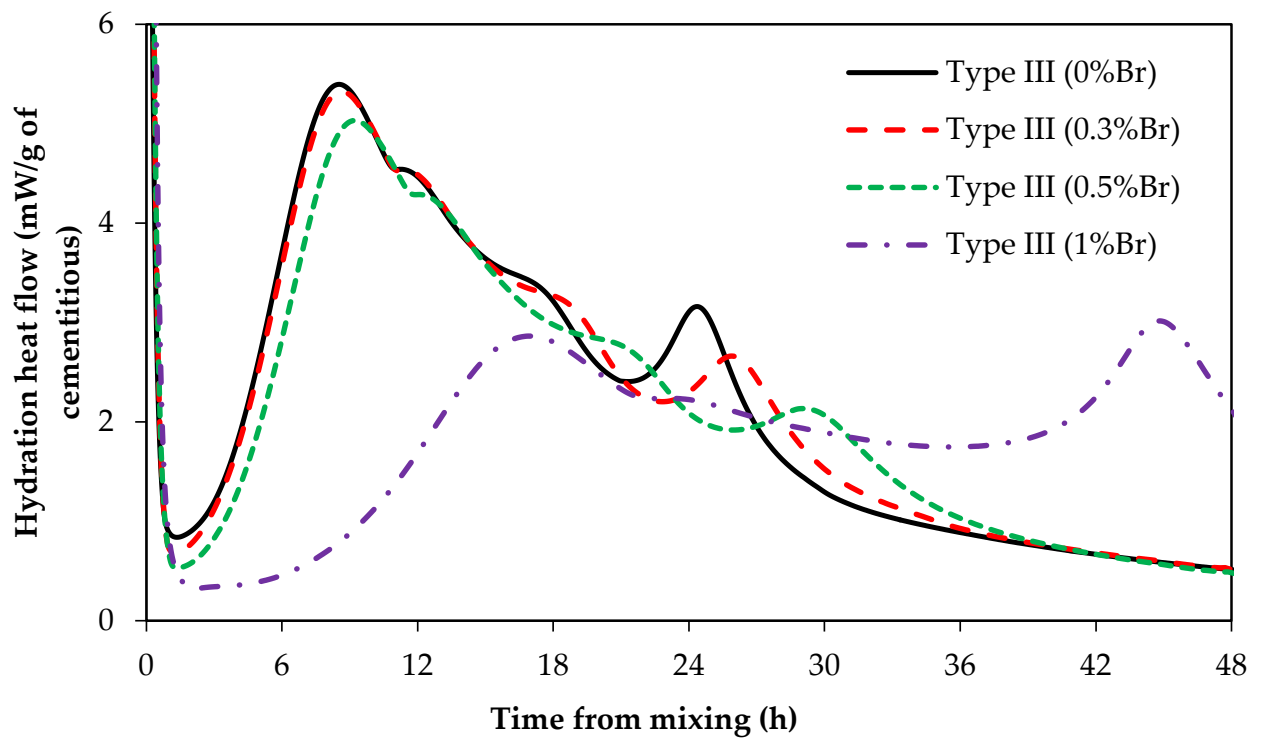

Figure 6. Type III hydration with and without borax.

Comparing Figure 2B with Figure 5 (or Figure 3B with Figure 6), it becomes clear that $\mathrm{ZnO}$ is a much stronger set time retarder than borax for Portland cement systems. Type II/V samples containing $0.5 \% \mathrm{ZnO}$ have a retardation time of about $50 \mathrm{~h}$ while type II/ $\mathrm{V}$ samples containing $0.5 \%$ borax $(0.5 \% \mathrm{Br}$ in Figure 5) have a retardation time of approximately $6 \mathrm{~h}$. Similarly, type III samples containing $0.5 \%$ $\mathrm{ZnO}$ have a retardation time of $38 \mathrm{~h}$ (Figure $3 \mathrm{~B})$, while type III samples with $0.5 \%$ borax $(0.5 \% \mathrm{Br}$ in Figure 6) have a retardation time of about $3 \mathrm{~h}$.

The other notable difference between paste samples containing borax and $\mathrm{ZnO}$ is that samples containing $\mathrm{ZnO}$ have a narrower but steep main hydration peak, whereas samples containing borax show wider but shallower main hydration peaks. The sharp narrow peaks in samples containing $\mathrm{ZnO}$ have been suggested to result from the high number of C-S-H nucleation sites in these samples [7]. Shallow hydration peaks in systems containing borax could suggest that borax limits dissolution of cement particles and thus reduces the number of C-S-H nuclei. The negligible effect of $0.3 \%$ and $0.5 \%$ borax on type III hydration could be attributed to the fact that type III has a high surface area, which means borax cannot reduce the cement dissolution at these lower dosages because there are more surfaces to be poisoned.

If the cement particle dissolution is reduced by borax, the number of C-S-H nuclei would be small, the rate of $\mathrm{C}-\mathrm{S}-\mathrm{H}$ formation and growth would be slower, and hence the hydration peak would be shallower. Therefore, it could be suggested that the mechanism by which $\mathrm{ZnO}$ and borax retard the cement set time is different; $\mathrm{ZnO}$ retards the set time by poisoning $\mathrm{C}-\mathrm{S}-\mathrm{H}$ nucleation and growth whereas borax prolongs the set time by poisoning/reducing cement dissolution. Borax could also poison the nucleation and/or growth of $\mathrm{C}-\mathrm{S}-\mathrm{H}$.

\subsection{Impact of $\mathrm{ZnO}$ and Borax on Calcium Aluminate Cement (CAC) Hydration}

Figure 7 shows the heat of hydration of CAC paste samples with and without $\mathrm{ZnO}$. Clearly, $\mathrm{ZnO}$ has no retarding effect, even at high dosages, on CAC hydration. Figure 8 shows the heat of hydration of CAC paste samples containing different dosages of borax, $0 \% \mathrm{Br}, 0.3 \% \mathrm{Br}, 0.5 \% \mathrm{Br}$, and $1 \% \mathrm{Br}$. Figure $8 \mathrm{~A}$ presents the heat flow and Figure $8 \mathrm{~B}$ shows the total heat of hydration. 


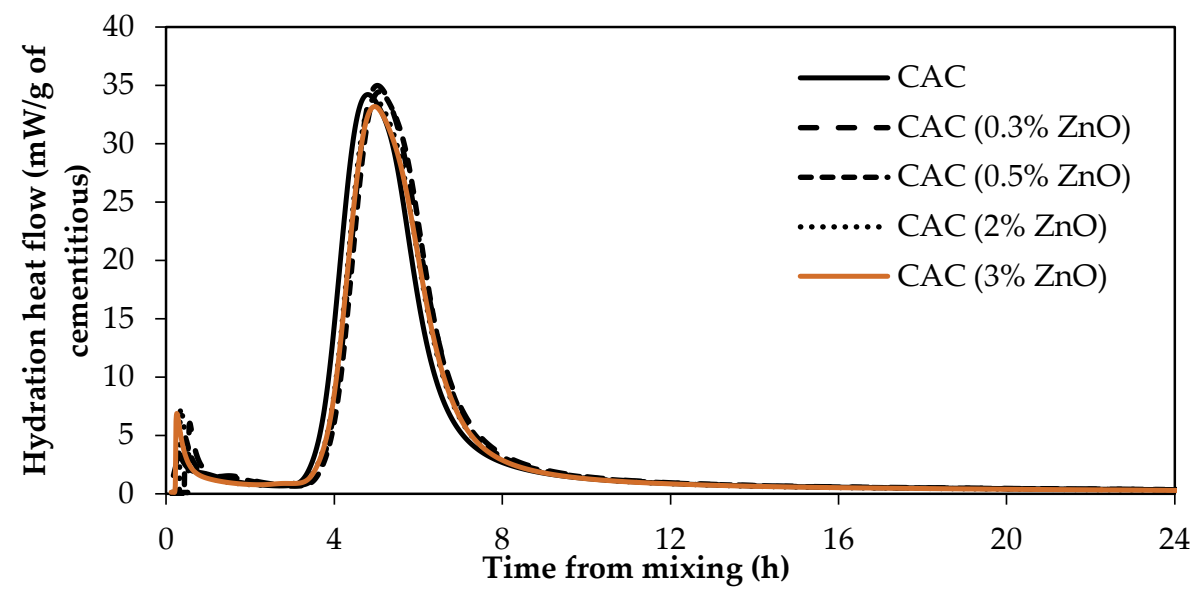

Figure 7. Heat of hydration of $\mathrm{CAC}$ with and without $\mathrm{ZnO}$ addition.
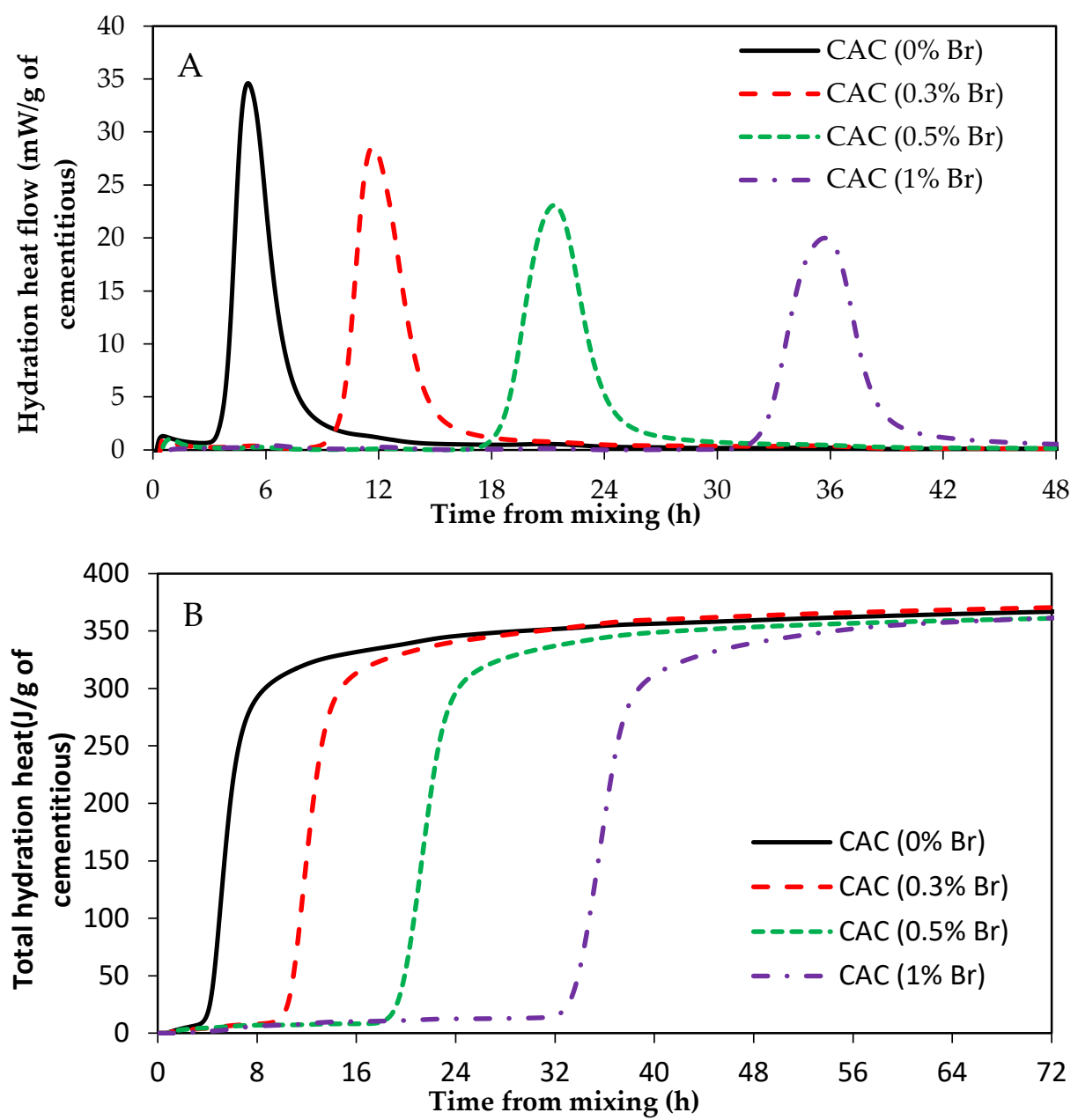

Figure 8. Heat of hydration of CAC with and without borax. (A) heat flow; (B) total heat.

As can been seen from Figure 8, addition of borax to CAC paste samples retarded the set time. Samples with $1 \%$ borax $(1 \% \mathrm{Br})$ had an induction period of about $32 \mathrm{~h}$, whereas samples with $0.3 \%$ $\mathrm{Br}$ had a retardation time of about $10 \mathrm{~h}$. Besides prolonging the induction period, borax reduced the CAC main hydration peak height as well (refer to Figure 8A). The higher the borax dosage in the mix, the lower the peak height. However, the main hydration peaks are wider in samples containing borax compared to those without borax. Shallower but wider hydration peaks for samples containing 
borax suggests that borax controls the rate of nucleation and/or growth of hydration products. As it was suggested earlier, this could be because borax suppresses the dissolution of phases in cement. Furthermore, borax could also poison the nucleation and/or growth of CAC hydration products.

Hydration reactions of CAC are different from that of Portland cement. The main hydration products of $\mathrm{CAC}$ are calcium aluminate hydrate and aluminate hydrate. At curing temperatures between $20^{\circ} \mathrm{C}$ and $30^{\circ} \mathrm{C}$, the hydration products of CAC are calcium aluminate hydrate (CAH10 and $\mathrm{C} 2 \mathrm{AH} 8$ ) and aluminate hydroxide (AH3). Therefore, it can be suggested that $\mathrm{ZnO}$ does not poison the nucleation and/or growth of $\mathrm{CAC}$ hydration products, nor does $\mathrm{ZnO}$ reduce the dissolution of CAC phases.

\subsection{Influence of $\mathrm{ZnO}$ and Borax on CSA Cement Hydration}

To study the influence of $\mathrm{ZnO}$ addition on CSA cement, the set time of CSA cement was delayed by three methods: (1) mixing 25\% CSA and 75\% type II/V cements, (2) adding 50\% citric acid, and (3) adding a chemical retarder. Citric acid and retarder were mixed with the mix water. Figure 9 shows the heat of hydration graphs for binary paste samples (25\% CSA and 75\% type II/V) with and without ZnO.

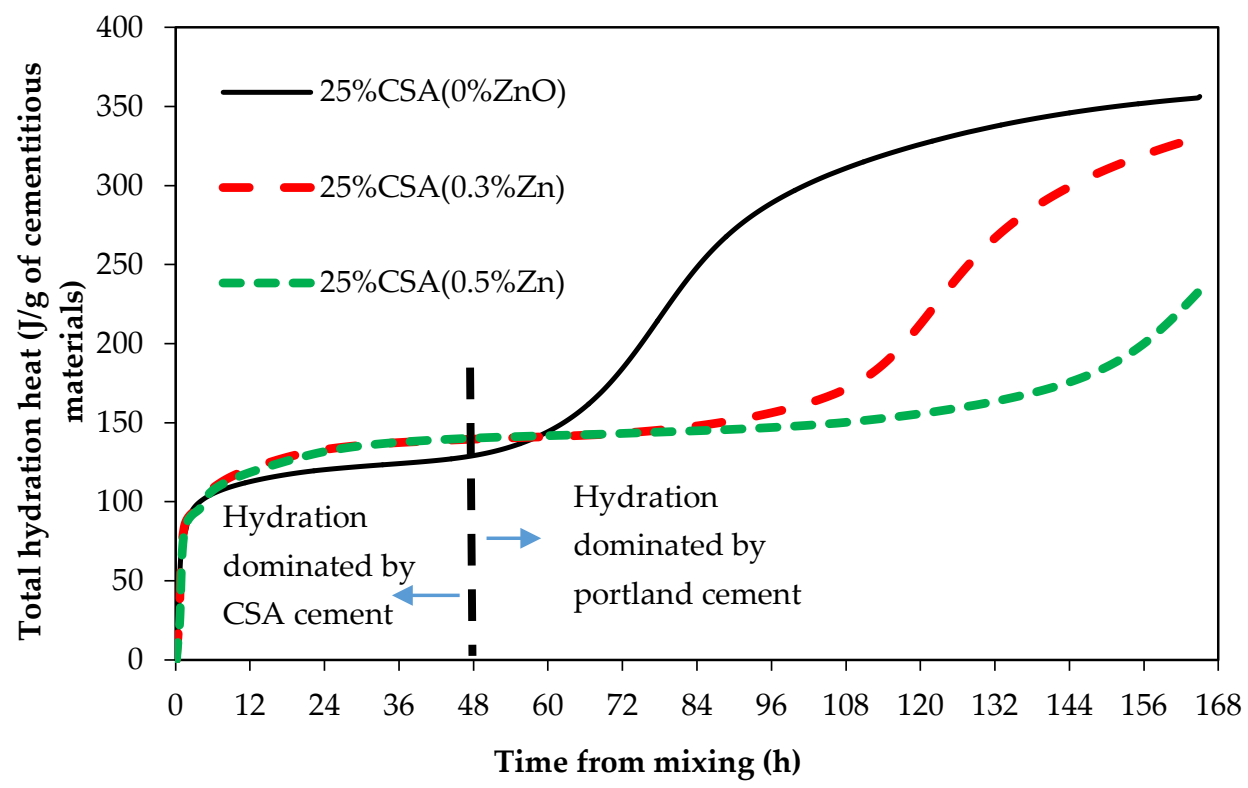

Figure 9. Total heat of hydration of samples containing 25\% CSA.

Hydration graphs in Figure 9 show two distinct hydration phases, one from initial mixing to around $48 \mathrm{~h}$, and the other one beginning at around $48 \mathrm{~h}$. The hydration process of cementitious systems containing CSA and Portland cement has been proposed to be a two phase process [20]. CSA hydration happens during the first phase and produces $\mathrm{AFm}, \mathrm{AFt}$, and aluminium hydroxide (AH3). The second phase of hydration is due to the hydration of C3S in Portland cement, which forms stratlingite (C2ASH8), C-S-H, and $\mathrm{CH}$ according to Equations (3) and (4) [20].

$$
\begin{gathered}
\mathrm{C}_{3} \mathrm{~S}+\mathrm{AH}_{3}+\mathrm{H} \rightarrow \mathrm{C}_{2} \mathrm{ASH}_{8}+\mathrm{CH} \\
\mathrm{C}_{3} \mathrm{~S}+\mathrm{H} \rightarrow \mathrm{CSH}+\mathrm{CH}
\end{gathered}
$$

Therefore, the first phase (up to $48 \mathrm{~h}$ ) of the hydration reaction observed in Figure 9 is dominated by CSA cement, while Portland cement hydration dominates the second phase (after $48 \mathrm{~h}$ ). As can be seen from Figure 9, hydration of CSA was not affected by $\mathrm{ZnO}$ addition as the first phase of hydration showed no retardation regardless of $\mathrm{ZnO}$ dosage. However, hydration of type II/V (the second phase of hydration) was delayed by $\mathrm{ZnO}$. 
Figure 10A shows the heat of hydration of CSA pastes samples made with $50 \%$ citric acid solution with and without $\mathrm{ZnO}$. Figure 10B shows hydration graphs for CSA cement paste samples dosed by a chemical retarder admixture (ASTM type B and D). Citric acid and retarder were used to delay the set time enough to allow sample preparation. In both Figure 10A,B, $\mathrm{ZnO}$ did not affect the hydration of CSA. Therefore, based on the ZnO performance in binary paste samples (Figure 8 ) and in $100 \%$ CSA cement paste samples (Figure 10), it can be suggested that $\mathrm{ZnO}$ doesn't have a retarding effect on the CSA set time. Thus, it can be concluded that $\mathrm{ZnO}$ has no poisoning effect on nucleation and/or growth of CSA main hydration products (ettringite (AFt) and aluminate hydroxide (AH3)).
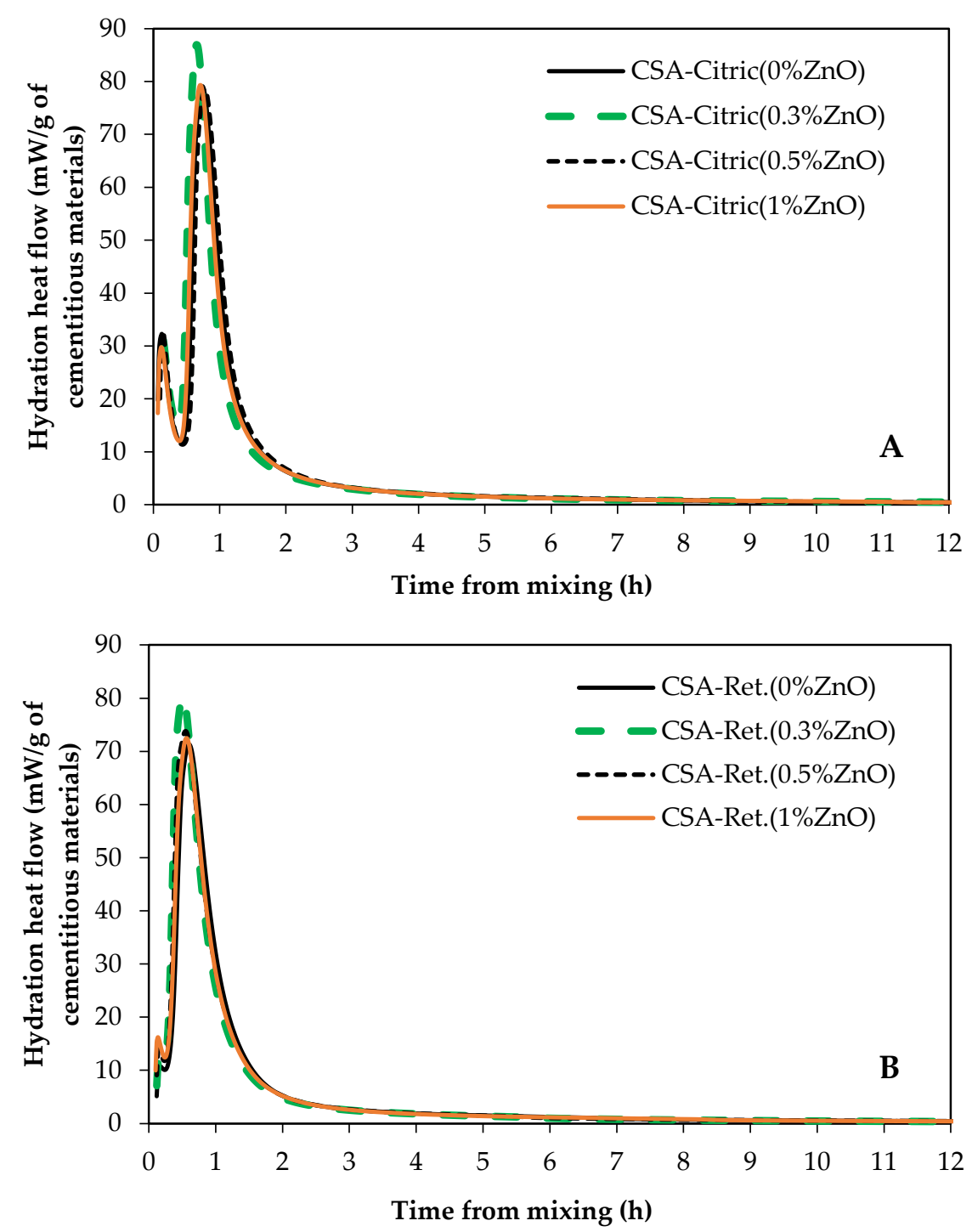

Figure 10. Hydration heat of CSA paste samples; (A) dosed by citric acid and (B) dosed by a chemical retarder admixture. 
Figure 11 shows the impact of borax on hydration of CSA paste samples mixed with $50 \%$ citric acid solution with and without borax. The sample containing $0.3 \%$ borax $(0.3 \% \mathrm{Br})$ had the same induction period compared to the control one $(0 \% \mathrm{Br})$. However, samples containing $0.5 \% \mathrm{Br}$ and $1 \% \mathrm{Br}$ had a longer induction period compared to the control sample. The induction period for the sample containing $1 \% \mathrm{Br}$ was longer than an hour, as it can be seen in Figure 11A. Besides prolonging the induction period, borax lowered the height of the main hydration peak. However, the total heat of hydration of CSA samples at $6 \mathrm{~h}$ after mixing was similar regardless of the borax dosage. The retardation due to borax could be because borax prevents the dissolution of ye'elimite (C4A3S), which is a major mineral phase in CSA cement [12].
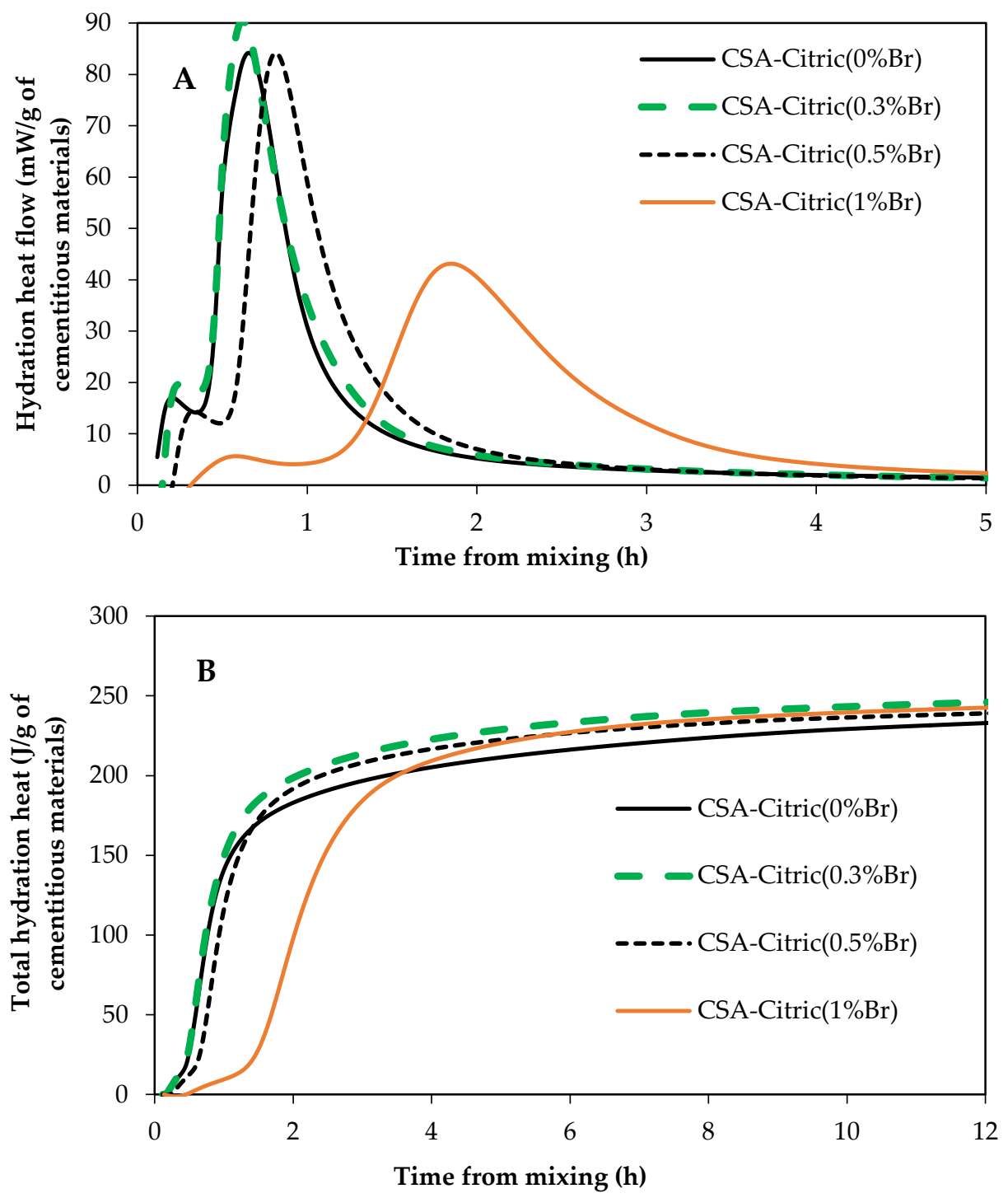

Figure 11. Influence of borax on CSA hydration; (A) heat flow and (B) total hydration heat. 


\section{Conclusions}

The retarding action of $\mathrm{ZnO}$ and borax on Portland cement, CSA cement, and CAC was investigated. The heat of hydration of cement paste samples with and without addition of $\mathrm{ZnO}$ and borax was measured to study the impact of $\mathrm{ZnO}$ and borax on the set time of cementitious systems. It was found that the retarding impacts of $\mathrm{ZnO}$ and borax on cementitious systems are different from each other. It was shown that both $\mathrm{ZnO}$ and borax can retard the set time of Portland cement systems; however, $\mathrm{ZnO}$ was found to be a stronger set time retarder than borax for Portland cement systems. However, the set time of CSA and CAC was not retarded by $\mathrm{ZnO}$, while borax retarded the set time of these cementitious systems. It was also revealed that as the curing temperature raises, the effectiveness of $\mathrm{ZnO}$ in retarding the set time decreases.

It can be concluded that the mechanism(s) by which the set time of cementitious systems is retarded by $\mathrm{ZnO}$ and by borax is different. It seems like $\mathrm{ZnO}$ does not suppress the nucleation and growth of CSA and CAC hydration products, which are mainly aluminate bearing phases such as ettringite and aluminate hydrate. It can also be suggested that borax retards the set time by reducing the dissolution of cement particles, whereas we suggest that $\mathrm{ZnO}$ poisons nucleation and/or growth of C-S-H.

Funding: This research was funded by the Office of Research and Sponsored Programs at California State University-Chico.

Acknowledgments: The author is thankful to Mitsubishi Cement, Buzzi Unicem USA, and Kerneos companies for donating the Portland cement, CSA cement, and CAC, respectively, for this research study.

Conflicts of Interest: The authors declare no conflict of interest. The funder had no role in the design of the study; in the collection, analyses, or interpretation of data; in the writing of the manuscript, or in the decision to publish the results.

\section{References}

1. Bishop, M.; Andrew, R.B. Cement Hydration Inhibition with Sucrose, Tartaric Acid, and Lignosulfonate: Analytical and Spectroscopic Study. Ind. Eng. Chem. Res. 2006, 45, 7042-7049. [CrossRef]

2. Thomas, J.J.; Jennings, H.M.; Chen, J.J. Influence of Nucleation Seeding on the Hydration Mechanisms of Tricalcium Silicate and cement. J. Phys. Chem. 2009, 113, 4327-4334. [CrossRef]

3. Juenger, M.C.G.; Jennings, H.M. New insights into the effects of sugar on the hydration and microstructure of cement pastes. Cement Concrete Res. 2002, 32, 393-399. [CrossRef]

4. Peterson, V.K.; Juenger, M.C.G. Hydration of Tricalcium Silicate: Effects of $\mathrm{CaCl}_{2}$ and Sucrose on Reaction Kinetics and Product Formation. Chem. Mater. 2006, 18, 5798-5804. [CrossRef]

5. Thomas, N.L.; Birchall, J.D. The retarding action of sugars on cement hydration. Cement Concrete Res. 1983, 13, 830-842. [CrossRef]

6. Cheung, J.; Jeknavorian, A.; Roberts, L.; Silva, D. Impact of admixtures on the hydration kinetics of Portland cement. Cement Concrete Res. 2011, 41, 1289-1309. [CrossRef]

7. Ataie, F.F.; Juenger, M.C.; Taylor-Lange, S.C.; Riding, K.A. Comparison of the retarding mechanisms of zinc oxide and sucrose on cement hydration and interactions with supplementary cementitious materials. Cement Concrete Res. 2015, 72, 128-136. [CrossRef]

8. de Rincon, O.T.; Perez, O.; Paredes, E.; Caldera, Y.; Urdaneta, C.; Sandoval, I. Long-term performance of ZnO as a rebar corrosion inhibitor. Cement Concrete Comp. 2002, 24, 79-87. [CrossRef]

9. Berke, N.S.; Caldarone, M.A. Zinc Oxide-A powerful retarding admixture. Concrete Int. 2013, 42-46.

10. Arliguie, G.; Grandet, J. Influence de la composition d'un ciment portland sur son hydration en presence de zinc. Cement Concrete Res. 1990, 20, 517-524. [CrossRef]

11. Hamilton, I.W.; Sammes, N.M. Encapsulation of steel foundry bag house dusts in cement mortar. Cement Concrete Res. 1999, 29, 55-61. [CrossRef]

12. Zajac, M.; Skocek, J.; Bullerjahn, F.; Haha, M.B. Effect of retarders on the early hydration of calcium-sulpho-aluminate (CSA) type cements. Cement Concrete Res. 2016, 84, 62-75. [CrossRef]

13. Ataie, F.F.; Riding, K.A. Influence of agricultural residue ash on early cement hydration and chemical admixtures adsorption. Constr. Build. Mater. 2016, 106, 274-281. [CrossRef] 
14. Ataie, F.F.; Riding, K.A. Thermochemical Pretreatments for Agricultural Residue Ash Production for Concrete. J. Mater. Civil Eng. 2012, 25, 1703-1711. [CrossRef]

15. Ataie, F.F.; Riding, K.A. Use of bioethanol byproduct for supplementary cementitious material production. Constr. Build. Mater. 2014, 51, 89-96. [CrossRef]

16. Chen, A.L.; Dong, X.U.; Chen, X.Y.; Zhang, W.Y.; Liu, X.H. Measurements of zinc oxide solubility in sodium hydroxide solution from 25 to $100{ }^{\circ} \mathrm{C}$. Trans. Nonferr. Metal. Soc. China 2012, 22, 1513-1516. [CrossRef]

17. Deschner, F.; Lothenbach, B.; Winnefeld, F.; Neubauer, J. Effect of temperature on the hydration of Portland cement blended with siliceous fly ash. Cement Concrete Res. 2013, 52, 169-181. [CrossRef]

18. ASTM C150/C150M, Standard Specification for Portalnd Cement; ASTM International: West Conshohocken, PA, USA, 2009.

19. Verbeck, G.J. Structures and physical properties of cement paste. In Proceedings of the 5th International Congress on the Chemistry of Cement, Tokyo, Japan, 7-11 October 1968; Volume 3, pp. 1-37.

20. Berger, R.L.; McGregor, J.D. Effect of temperature and water-solid ratio on growth of $\mathrm{Ca}(\mathrm{OH})_{2}$ crystals formed during hydration of $\mathrm{Ca}_{3} \mathrm{SiO}_{5}$. J. Am. Ceramic Soc. 1973, 56, 73-79. [CrossRef]

(C) 2019 by the author. Licensee MDPI, Basel, Switzerland. This article is an open access article distributed under the terms and conditions of the Creative Commons Attribution (CC BY) license (http://creativecommons.org/licenses/by/4.0/). 